demur by both the Faculty Office of the Archbishop of Canterbury and the Registrar General's Office within the last decade and a half. Inevitably, there was widespread suspicion that the Bench had acted unilaterally in order to circumvent the risk of further defeat in the Governing Body. There was also considerable dissatisfaction with the manner in which the statement had been issued to the press before many clergy received their copies of it.

Resentment on both counts led to an unsuccessful attempt to amend the motion by dividing it into two parts, one welcoming the statement and the other supporting the guidelines. Following the defeat of the amendment, however, a point of order was raised by the Revd Stephen Kirk, a law graduate who is also a graduate from the Cardiff Master's course in canon law. He queried whether it was open to the Governing Body to welcome a statement which arguably contradicted the doctrine and teaching of the Church in Wales as enshrined in canons passed by the Governing Body. The canons in question were those for Revision of the Book of Common Prayer (Holy Matrimony), promulgated in 1974, and for Revision of the Book of Common Prayer (The Catechism), promulgated in 1982. The former contains the rubric that:

The Church teaches that marriage is the lifelong union of one man and one woman, and is dissolved only by the death of either party

while the latter states, in answer to the question:

What is Holy Matrimony?

Holy Matrimony is a life-long union, instituted by God, into which a man and a woman enter.

After adjourning to take the advice of his Assessor, the Chairman ruled that the point of order prima facie contained an arguable issue of substance and that it would therefore be improper for the Governing Body to consider the motion as the statement it purported to welcome might be challenged before the Church's own courts. Accordingly, the motion was withdrawn. The Governing Body did, however, give leave for the proposed guidelines to be discussed. An informal discussion ensued, and the guidelines are to be finalised later this summer. However, there remains a distinct sense of unease in the relationship between the Bench of Bishops and the Governing Body and uncertainty about the exact status of the episcopal statement following the success of the point of order and the Chairman's ruling. The bishops have, however, made it clear that, as far as they are concerned, their statement stands.

\title{
THE GENERAL SYNOD OF THE CHURCH OF IRELAND
}

\section{MICHAEL DAVEY}

The Bills which were brought successfully to General Synod this year were administrative in nature.

The first Bill was presented at the request of the House of Bishops. On the election of an Archbishop of Armagh, or the election or confirmation of election by the House of Bishops of a person already in Episcopal Orders, there was no provision in the Constitution for any delay in taking up office. The purpose of the Bill was to enable the House of Bishops to determine the date, within a period of 3 months from the date of the election, upon which such translation would take place.

The second Bill proposed a number of improvements in the benefits provided by the Pensions Fund. Normal pensionable age was reduced from 67 to 65 . The manner of calculation of years and months of service was revised as were the arrangements 
for the purchase of additional years of service. The pensions of surviving spouses were increased, including the pensions of the widows of clergy who died or retired before 1976. The pensions of retired archbishops and widows of archbishops were also increased and a number of arrangements for deferred pensions and death benefit were revised.

A third Bill was passed to allow an overlap of membership between the Chapters of the Cathedral Churches of St Bridget of Kildare and St Patrick at Trim. The Statutes relating to these Cathedrals predated the uniting of the two dioceses. The Bill did not seek to amalgamate the two Chapters.

Two other bills were introduced, one to re-organise the united Chapters of the Cathedral Churches of St Canice, Kilkenny and St Laserian, Leighlin. The other was to obtain authorisation for the sale of certain pieces of silver plate donated for use in the Cathedral of St Colman, Cloyne or in certain churches in Cloyne Union which had been closed for public worship. These bills failed at the first and third reading respectively.

A resolution was also passed, with the required two thirds majority, to enable the introduction of bills in the General Synod of 1999 to provide for the use, in Churches and Chapels of the Church of Ireland, of the revised Common Lectionary and for the alteration of the Directions for Public Worship accordingly.

No other legislation was introduced. Legislation was foreshadowed in the report of the Commission on Episcopal Needs which recommended the alteration of some episcopal boundaries in the future. The Standing Committee of the General Synod has been charged with the task of preparing the necessary legislation. It seems likely to create considerable interest when it comes before the Synod in due course. 